\title{
TRAIL-induced apoptosis requires Bax-dependent mitochondrial release of Smac/DIABLO
}

\author{
Yibin Deng, Yahong Lin, and Xiangwei $\mathrm{Wu}^{1}$ \\ Huffington Center on Aging and Department of Molecular and Cellular Biology, Baylor College of Medicine, \\ Houston, Texas 77030, USA
}

\begin{abstract}
Recent reports suggest that a cross-talk exists between apoptosis pathways mediated by mitochondria and cell death receptors. In the present study, we report that mitochondrial events are required for apoptosis induced by the cell death ligand TRAIL (TNF-related apoptosis-inducing ligand) in human cancer cells. We show that the Bax null cancer cells are resistant to TRAIL-induced apoptosis. Bax deficiency has no effect on TRAIL-induced caspase- 8 activation and subsequent cleavage of Bid; however, it results in an incomplete caspase-3 processing because of inhibition by XIAP. Release of Smac/DIABLO from mitochondria through the TRAIL-caspase-8-tBid-Bax cascade is required to remove the inhibitory effect of XIAP and allow apoptosis to proceed. Inhibition of caspase-9 activity has no effect on TRAIL-induced caspase-3 activation and cell death, whereas expression of the active form of Smac/DIABLO in the cytosol is sufficient to reconstitute TRAIL sensitivity in Bax-deficient cells. Our results show for the first time that Bax-dependent release of Smac/DIABLO, not cytochrome $c$, from mitochondria mediates the contribution of the mitochondrial pathway to death receptor-mediated apoptosis.
\end{abstract}

[Key Words: Apoptosis; mitochondria; death receptor; Smac/DIABLO; XIAP; TRAIL]

Received October 9, 2001; revised version accepted November 15, 2001.

The signaling events leading to apoptosis can be divided into two distinct pathways, involving either mitochondria or death receptors (for reviews, see Ashkenazi and Dixit 1998; Green and Reed 1998). In the mitochondria pathway, death signals lead to changes in mitochondrial membrane permeability and the subsequent release of pro-apoptotic factors involved in various aspects of apoptosis (for review, see Green and Reed 1998). The released factors include cytochrome $c$ (cyto $c$; Liu et al. 1996), apoptosis inducing factor (AIF; Susin et al. 1999), second mitochondria-derived activator of caspase (Smac/DIABLO; Du et al. 2000; Verhagen et al. 2000), and endonuclease G (Li et al. 2001). Cytosolic cyto $c$ forms an essential part of the apoptosis complex "apoptosome," which is composed of cyto $c$, Apaf-1, and procaspase-9. Formation of the apoptosome leads to the activation of caspase-9, which then processes and activates other caspases to orchestrate the biochemical execution of cells. Smac/DIABLO is also released from the mitochondria along with cyto $c$ during apoptosis, and it functions to promote caspase activation by inhibiting IAP (inhibitor of apoptosis) family proteins (Du et al. 2000; Verhagen et al. 2000).

${ }^{1}$ Corresponding author.

E-MAIL xiangwei@bcm.tmc.edu; FAX (713) 798-4161.

Article and publication are at http://www.genesdev.org/cgi/doi/10.1101/ gad.949602.
The IAP family proteins negatively regulate apoptosis by inhibiting caspase activity directly. Six human IAPs have been discovered. They regulate apoptosis by preventing the action of the central execution phase of apoptosis through direct inhibition of the effector caspase-3 and/or caspase-7 (Deveraux et al. 1997, 1998). In addition, they prevent initiation of the intrinsic caspase activation cascade by directly inhibiting the apical caspase-9. Structural and biochemical dissection of XIAP, a widely expressed IAP member, reveals that the conserved BIR domains of XIAP mediate both its inhibitory activity on caspases and the protein-protein interaction with Smac/DIABLO. Binding of Smac/DIABLO to XIAP antagonizes caspase-XIAP interaction, thereby promoting apoptosis (for review, see Goyal 2001). Recent studies have shown that XIAP is highly expressed in most human cancer cells and that high levels of XIAP confer tumor resistance to chemotherapy or irradiation (Holcik et al. 2000; Sasaki et al. 2000).

The key regulatory proteins of mitochondria-mediated apoptotosis are the Bcl-2 family of proteins, which can either promote cell survival, as Bcl-2 and Bcl-xl do, or induce cell death, as Bax and Bak do. Bcl-2 and Bcl-xl appear to directly or indirectly preserve the integrity of the outer mitochondrial membrane, thus preventing cyto $c$ release and mitochondria-mediated cell death initiation, whereas the pro-apoptotic proteins Bax and Bak promote cyto $c$ release from mitochondria (Shimizu et al. 
1999). Bax has been implicated in apoptosis in many cell types under various conditions. More recently, studies using Bax-deficient human colon cancer cells have provided direct evidence that Bax plays a key role in mediating apoptosis induced by certain anti-cancer agents (Zhang et al. 2000). The Bax protein exerts at least part of its activity by triggering cyto $c$ release from mitochondria. Bax is in a predominantly cytosolic latent form in healthy cells and translocates to mitochondria after death signal stimulation (Hsu et al. 1997). Accumulating evidence suggests that Bax translocation is required for its pro-apoptotic function and that regulation of Bax's association with the mitochondrial membrane represents a critical step in the transduction of apoptotic signals (Deng and Wu 2000).

In the death receptor pathway, the apoptotic events are initiated by engaging the tumor necrosis factor (TNF)family receptors, including TNFR1, Fas, DR-3, DR-4, and DR-5. Upon ligand binding or when overexpressed in cells, TNF receptor family members aggregate, resulting in the recruitment of an adapter protein called FADD. The receptor-FADD complex then recruits procaspase-8. This allows proteolytic processing and activation of the receptor-associated procaspase-8, thereby initiating the subsequent cascade of additional processing and activation of downstream effector caspases (for reviews, see Nagata 1997; Ashkenazi and Dixit 1998).

TRAIL/Apo2L (NF-related apoptosis-inducing ligand TRAIL or Apo2 ligand) is an apoptosis-inducing member of the TNF gene superfamily (Wiley et al. 1995; Pitti et al. 1996). Unlike TNF- $\alpha$ and FasL, TRAIL appears to specifically kill transformed and cancer cells while leaving normal cells intact (French and Tschopp 1999). Preclinical experiments in mice and nonhuman primates have shown that administration of TRAIL suppresses tumor growth without apparent systematic cytotoxicity (Ashkenazi et al. 1999; Walczak et al. 1999). Therefore, TRAIL represents a promising anti-cancer agent. TRAIL interacts with four cellular receptors that form a distinct subgroup within the TNFR superfamily (Pan et al. 1997a,b; Sheridan et al. 1997). Most recent experiments have shown that FADD and procaspase- 8 associate with the endogenous TRAIL receptors DR4 and DR5 (Kischkel et al. 2000; Sprick et al. 2000; Miyazaki and Reed 2001). FADD and caspase- 8 are required for TRAIL-induced apoptosis (Bodmer et al. 2000). Thus, TRAIL/ Apo2L and FasL appear to engage similar pathways to apoptosis.

Although the extrinsic pathway (through the death receptors) and the intrinsic pathway (through the mitochondria) for apoptosis are capable of operating independently, accumulating evidence suggests that a cross-talk between the two pathways exists in cells (for review, see Green 1998). The link between death receptor signaling and the mitochondrial pathway comes from the finding that a BH3-domain-only subfamily protein, Bid, is cleaved by active caspase- 8 . The truncated Bid (tBid) translocates to mitochondria and triggers cyto $c$ release (Li et al. 1998; Luo et al. 1998). It has been proposed that tBid regulates cyto $c$ release by inducing the homo-oligo- merization of pro-apoptotic family members Bak or Bax. Cells lacking both Bax and Bak, but not cells lacking just one of these components, are completely resistant to tBid-induced cyto $c$ release and apoptosis (Wei et al. 2001).

Bid appears to link the intrinsic pathway to the cell death receptor-mediated apoptosis. However, the precise mitochondrial events required for this cross-talk remain unclear. The mechanisms of TRAIL-induced apoptosis and the role of mitochondria in the cell death receptor pathway also need further investigation. Using human colon cancer cells defective in Bax function, we show that mitochondrial events are required for TRAIL-induced apoptosis. We discovered that the reason for this requirement is the presence of negative regulation of caspase cascade by XIAP. Activation of the mitochondrial pathway leads to the release of Smac/DIABLO, which removes XIAP blockage of caspase activation. Our results further show that release of Smac/DIABLO, not cyto $c$, is the key event mediating the contribution of the mitochondrial pathway to the death receptor-mediated apoptosis. By systematically examining various molecular events and molecules involved in both mitochondrial and death receptor pathways in a single genetic system, we are able to present a genetic pathway that shows how the mitochondrial pathway is required for death receptor-induced apoptosis.

\section{Results}

Expression of Bax is required for TRAIL-induced apoptosis in human colon cancer cells

As a first step to explore the involvement of mitochondrial events in TRAIL-induced apoptosis, a stable cell line overexpressing Bcl-xl (Bax $\left.{ }^{+/-} / \mathrm{Bcl}-\mathrm{xl}\right)$ was established by transfecting a Bcl-xl expression plasmid into $\mathrm{Bax}^{+/-}$ cells. The $\mathrm{Bax}^{+/-}$cells are derivatives of HCT116 human colon cancer cells containing only one allele of the wildtype $B A X$ gene. Compared with the control $\mathrm{Bax}^{+/-} /$neo cells, the $\mathrm{Bax}^{+/-} / \mathrm{Bcl}-\mathrm{xl}$ cells expressed approximately fivefold higher levels of Bcl-xl (Fig. 1A). TRAIL treatment induced apoptosis in $95 \%$ of control $\mathrm{Bax}^{+/-} /$neo cells, but TRAIL-induced apoptosis was completely suppressed in $\mathrm{Bax}^{+/-} / \mathrm{Bcl}-\mathrm{xl}$ cells (Fig. 1B). No cell death was observed after exposing $\mathrm{Bax}^{+/-} / \mathrm{Bcl}-\mathrm{xl}$ cells to TRAIL treatment for $24 \mathrm{~h}$ (data not shown). Apoptosis was characterized by DNA fragmentation, cleavage of procaspase3 , and caspase substrate PARP (data not shown). The ability of Bcl-xl to inhibit TRAIL-induced apoptosis suggests that the death signaling cascade through mitochondria represents an important component in TRAIL-induced apoptosis in cancer cells.

To further investigate the contribution of mitochondria in TRAIL-induced apoptosis, we took advantage of a Bax knockout cell line $\left(\mathrm{Bax}^{-/-}\right)$derived from $\mathrm{Bax}^{+/-}$cells by Zhang et al. (2000). Lack of Bax expression in $\mathrm{Bax}^{-/-}$ cells was first confirmed by Western blot analysis (Fig. 1C). Most $\mathrm{Bax}^{+/-}$cells undergo apoptosis with characteristic morphological changes after $6 \mathrm{~h}$ of treatment with 
A

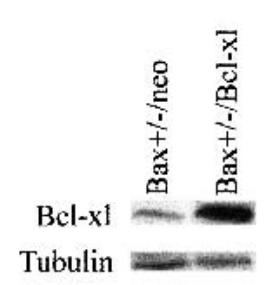

D

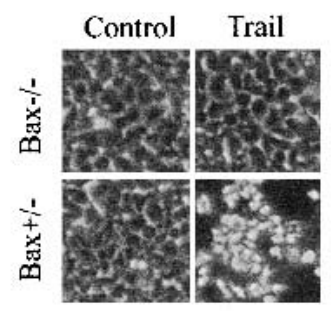

B

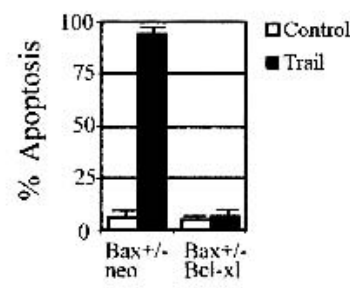

E

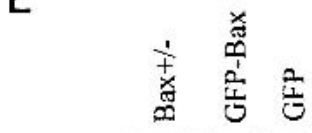

GFP-Bax

Bax

Actin

F
C
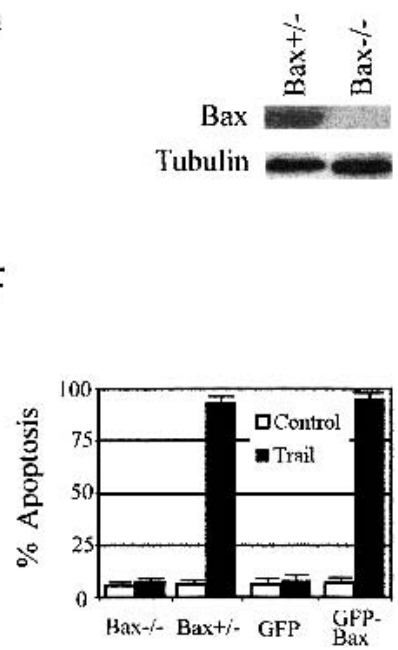

Figure 1. Requirement of Bax in TRAIL-induced apoptosis. (A) Western analysis of Bcl-xl expression in the Bax ${ }^{+/-} / \mathrm{Bcl}_{-}-\mathrm{xl}$ stable cell line and the control $\mathrm{Bax}^{+/-} /$neo cell line. Whole cell extracts were used. Expression of tubulin was used as a control. $(B)$ Suppression of TRAIL-induced apoptosis in $\mathrm{Bax}^{+/} / \mathrm{Bcl}-\mathrm{xl}$ cells. Cells were treated with TRAIL for $6 \mathrm{~h}$, apoptosis was measured by trypan blue exclusion, and data from three independent experiments were plotted with standard deviations. (C) Western analysis of Bax expression in $\mathrm{Bax}^{+-}$and $\mathrm{Bax}^{-/-}$cells. (D) Morphology of TRAIL-treated $\mathrm{Bax}^{+/-}$and $\mathrm{Bax}^{-/-}$cells. The picture was taken $6 \mathrm{~h}$ after TRAIL treatment. (E) Comparing the expression of GFP-Bax protein in GFP-Bax stable cell lines derived from Bax ${ }^{-/-}$cells with Bax expression in Bax ${ }^{+/-}$ cells. Cells expressing GFP only were used as a negative control. Whole cell extracts were analyzed. (F) TRAIL-induced apoptosis in $\mathrm{Bax}^{-/-}, \mathrm{Bax}^{+/-}$, GFP, and GFP-Bax cells. Cells were treated with TRAIL (100 ng/mL) for $6 \mathrm{~h}$, apoptosis was measured by trypan blue exclusion, and data from three independent experiments were plotted with standard deviations.

TRAIL, whereas little apoptosis was observed in $\mathrm{Bax}^{-/-}$ cells (Fig. 1D,F). Treatment of Bax $^{-/-}$cells with a 10 -fold higher concentration of TRAIL for $48 \mathrm{~h}$ did not result in significant cell death (data not shown), suggesting that Bax is required for TRAIL-induced apoptosis in human colon cancer cells.

To test whether restoring Bax expression in $\mathrm{Bax}^{-/-}$ cells could rescue TRAIL-induced apoptotic response, Bax was reintroduced into $\mathrm{Bax}^{-/-}$cells. A plasmid expressing a Bax protein fused with the green fluorescent protein (GFP) in frame was transfected into $\mathrm{Bax}^{-/-}$cells, and stable cell lines (GFP-Bax) were established expressing the GFP-Bax protein. The GFP-Bax fusion protein retained wild-type Bax function (Deng and $\mathrm{Wu} 2000$ ). Ectopic expression of GFP-Bax in $\mathrm{Bax}^{-/-}$cells restored Bax expression to a level similar to that of $\mathrm{Bax}^{+/-}$cells (Fig. 1E). Like the parental $\mathrm{Bax}^{-/-}$cells, the control GFPexpressing $\mathrm{Bax}^{-/-}$cells (GFP) showed no cell death after TRAIL treatment (Fig. 1F). However, Bax-reconstituted GFP-Bax cells displayed pronounced apoptosis following TRAIL stimulation (Fig. 1F). These results strongly support the hypothesis that Bax-induced mitochondrial events are required for TRAIL-induced apoptosis in human colon cancer cells.

Loss of Bax had no effect on TRAIL-induced caspase-8 activation and Bid cleavage, but inhibited mitochondrial release of Smac/DIABLO and cyto c

To investigate whether Bax deficiency affects TRAILmediated caspase activation after TRAIL stimulation, procaspase- 8 cleavage and subsequent downstream Bid cleavage were examined. Caspase- 8 and Bid protein levels were first analyzed by Western blots in $\mathrm{Bax}^{+/-}$and $\mathrm{Bax}^{-1-}$ cells following TRAIL stimulation. Reduction of procaspase- 8 and the corresponding appearance of processed caspase- 8 were observed as early as $1 \mathrm{~h}$ after TRAIL treatment, and almost all procaspase- 8 was cleaved after $4 \mathrm{~h}$ of treatment (Fig. 2A). A corresponding decrease in full-length Bid protein levels was observed, suggesting that the full-length Bid protein is cleaved by the activated caspase- 8 . More importantly, both $\mathrm{Bax}^{+/-}$ and $\mathrm{Bax}^{-/-}$cells showed almost identical patterns (Fig. 2A), suggesting that the loss of Bax did not block TRAILmediated caspase- 8 activation and subsequent cleavage of Bid.

One of the events mediated by Bax is the release of cyto $c$ from mitochondria, followed by procaspase-9 activation. The Smac/DIABLO protein was also redistributed from mitochondria to cytosol during mitochondriainitiated apoptosis, concurrent with cyto $c$ relocalization (Du et al. 2000; Verhagen et al. 2000). Therefore, we investigated if loss of Bax could block Smac/DIABLO and cyto $c$ release and procaspase- 9 activation in the TRAIL signaling pathway. Immunostaining of Smac/DIABLO and cyto $c$ showed a bright staining pattern around the nuclei representing typical mitochondria localization in $\mathrm{Bax}^{+/-}$and $\mathrm{Bax}^{-/-}$cells before TRAIL treatment (Fig. 2B). Stimulation by TRAIL induced obvious redistribution of cyto $c$ and Smac/DIABLO in $\mathrm{Bax}^{+/-}$cells. The staining pattern became diffused in most cells, suggesting that the proteins were released into the cytosol (Fig. 2B). In 
Deng et al.

A

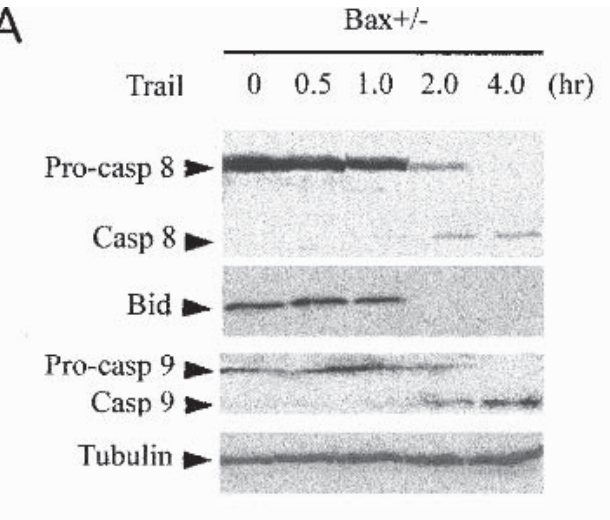

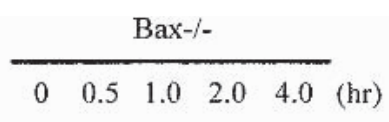

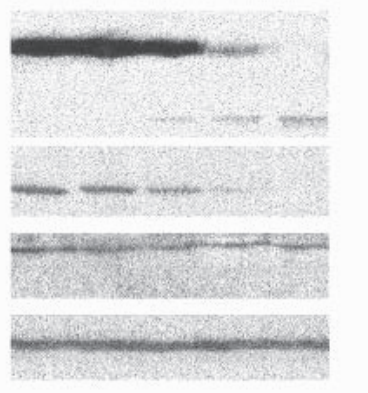

B

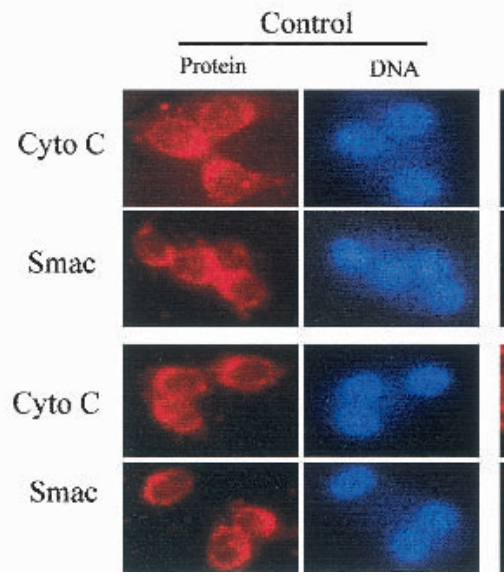

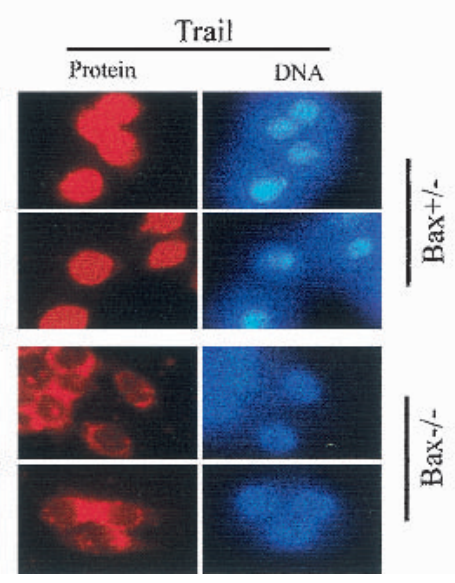

C

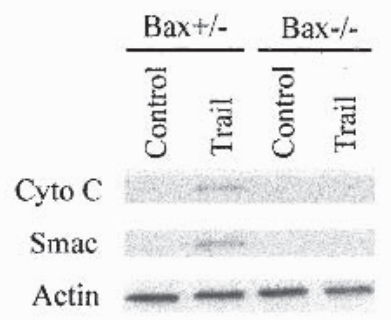

D

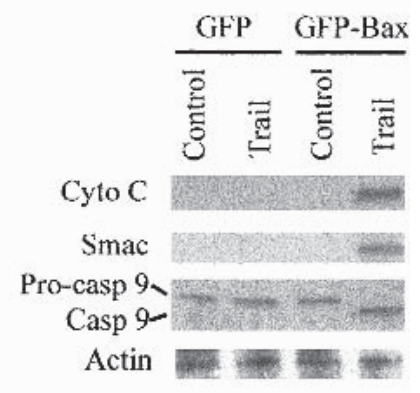

Figure 2. Bax-dependent mitochondrial changes after TRAIL treatment. (A) Activation of caspase- 8 and caspase-9 by TRAIL. Whole cell extracts were prepared at different times after TRAIL stimulation as indicated. Western blotting were performed to analyze for cleavage of procaspase-8, procaspase-9, and Bid. Tubulin was used as a loading control. $(B)$ Immunostaining of cytochrome $c$ and Smac/DIABLO. Cells grown on chamber slides were treated by TRAIL for $2 \mathrm{~h}$ and stained using anti-cyto $c$ or Smac antibodies after fixing. DNA was visualized by Hoechst 3342. (C) Subcellular fraction of cyto $c$ and Smac/DIABLO. Subcellular fraction was performed on cells before and after TRAIL treatment. The cytosol fraction was subject to Western analysis. Cytosolic $\beta$-actin was used as the loading control. $(D)$ Distribution of cyto $c$ and Smac/DIABLO, activation of caspase-9 in Bax reconstituted cells. Cytosol extracts from TRAIL-treated and -untreated GFP- and GFP-Bax-expressing Bax ${ }^{-/-}$cells were analyzed for cyto $c$, Smac/DIABLO, and cleavage of caspase-9. Actin is the loading control.

contrast, the cyto $c$ and Smac/DIABLO staining in $\mathrm{Bax}^{-/-}$ cells remained unchanged after TRAIL treatment (Fig. 2B). Subcellular fraction analysis of cyto $c$ and Smac/ DIABLO proteins further supported the immunostaining results. Cyto $c$ and Smac/DIABLO proteins were detected in the soluble cytosolic fraction in response to TRAIL treatment in $\mathrm{Bax}^{+/-}$cells, and protein relocalization was not observed in $\mathrm{Bax}^{-/-}$cells (Fig. 2C), indicating that loss of Bax inhibited mitochondrial release of cyto $c$ and Smac/DIALO in response to TRAIL.

Cyto $c$ is a cofactor for Apaf-1-dependent caspase-9 activation (Li et al. 1997). To investigate if loss of Bax resulted in an inhibition in caspase- 9 activation in the TRAIL signaling pathway, $\mathrm{Bax}^{+/-}$and $\mathrm{Bax}^{-/-}$cells were treated with TRAIL, and cell lysates were immunoblotted with an anti-caspase-9 antibody. The cleaved caspase- 9 appeared in $\mathrm{Bax}^{+/-}$cells $2 \mathrm{~h}$ after TRAIL treatment, and procaspase- 9 disappeared $4 \mathrm{~h}$ after TRAIL exposure. In contrast, procaspase- 9 cleavage was absent in
$\mathrm{Bax}^{-/-}$cells (Fig. 2A). No procaspase-9 cleavage was observed in $\mathrm{Bax}^{-/-}$cells even after $24 \mathrm{~h}$ of TRAIL treatment (data not shown). Consistent with the finding that cyto $c$ release is absent in these cells, the data showed that procaspase-9 activation in response to TRAIL is inhibited by the loss of Bax. Similar results were obtained in GFP-Bax cells, in which expression of GFP-Bax restored the release of cyto $c$ and Smac/DIABLO from mitochondria and procaspase-9 activation upon TRAIL treatment (Fig. 2D), but had no effect on caspase-8 processing and Bid cleavage (data not shown). These results show that the mitochondrial pathway is activated by TRAIL treatment in a Bax-dependent manner.

\section{Bax translocation is required for TRAIL-mediated apoptosis}

To explore whether Bax translocation is involved in TRAIL-mediated apoptosis, $\mathrm{Bax}^{+/-}$cells were treated by 
TRAIL, and Bax localization was examined by subcellular fraction followed by Western blots. The Bax protein was located in the cytosol before TRAIL treatment and was redistributed to mitochondria after TRAIL treatment (Fig. 3A), suggesting that TRAIL induces Bax translocation. The redistribution of Bax was also observed in GFP-Bax cells. The GFP fluorescence indicated that GFP-Bax changed from a diffused cytosolic pattern to a punctate staining pattern representing typical mitochondrial staining following TRAIL treatment, whereas GFP fluorescence in control GFP cells showed no such change (Fig. 3C). To further investigate the requirement of Bax translocation in TRAIL-induced cell death, a mutant Bax deleting 21 amino acids at its $\mathrm{C}$ terminus (Bax $\Delta C 21)$ was generated as a GFP fusion protein. The C-terminal 21 amino acids containing the mitochondrial transmembrane domain are required for Bax translocation during apoptosis, and $B a x \Delta C 21$ retained apoptotic potential as reported (Jurgensmeier et al. 1998). Cell lines expressing GFP-Bax $\Delta$ C21 protein were established (Fig. 3B). In contrast to the GFP-Bax cells, addition of TRAIL to GFP$\mathrm{Bax} \Delta \mathrm{C} 21$-expressing cells caused neither Bax redistribution nor cell death as indicated by the lack of caspase substrate PARP cleavage (Fig. 3C,D), whereas caspase- 8 processing and Bid cleavage in GFP-Bax $\Delta \mathrm{C} 21$ cells remained unchanged (data not shown). These results suggest that Bax translocation from the cytosol to mitochondria is required for TRAIL-induced apoptosis.

The involvement of caspase- 8 and tBid in TRAIL-induced Bax translocation was subsequently examined. Addition of caspase-8 inhibitor strongly inhibited TRAIL-induced GFP-Bax translocation and cell death (data not shown), suggesting that Bax translocation depends on caspase- 8 activation in the TRAIL-mediated cell death pathway. To explore the role of tBid in the TRAIL-induced cancer cell death pathway and to test whether tBid-induced cell death requires Bax, we transfected a plasmid expressing the tBid protein into $\mathrm{Bax}^{+/-}$ and $\mathrm{Bax}^{-/-}$cells. Expression of tBid induced significant apoptosis only in the $\mathrm{Bax}^{+/-}$cells (data not shown), sug- gesting that Bax is required for tBid-induced cell death. Expression of $\mathrm{tBid}$ resulted in redistribution of Bax from the cytosol to mitochondria (data not shown), indicating that expression of tBid leads to Bax translocation.

Bax deficiency prevents complete caspase-3 processing, activation, and substrate cleavage

Caspase- 3 is a downstream effector caspase and can be activated by both caspase- 8 and caspase-9 (Li et al. 1997; Kuida et al. 1998; Stennicke et al. 1998). Because loss of Bax preferentially blocked procaspase- 9 cleavage and had no effect on caspase- 8 activation in TRAIL-mediated apoptosis (Fig. 2A), we proceeded to determine if caspase- 3 activation was also inhibited. Previous studies have shown that processing of procaspase- 3 involves an initial cleavage generating a p12 small subunit and a p24 partially processed large subunit. The p24 large subunit is further processed by autocatalytic removal of its $\mathrm{N}$ terminal pro-domain to generate either a p20 or a p17 polypeptide (Martin et al. 1996). To evaluate the status of caspase- 3 processing and activation, $\mathrm{Bax}^{+/-}$and $\mathrm{Bax}^{-/-}$ cells were treated with TRAIL, and extracts were immunoblotted with an anti-caspase- 3 antibody. TRAIL treatment of $\mathrm{Bax}^{+/-}$cancer cells resulted in a decrease in procaspase-3 levels and appearance of three cleavage products: p24, p20, and p17 (the antibody used does not recognize p12; Fig. 4A). Although $\mathrm{Bax}^{-/-}$cancer cells also displayed a decrease in procaspase- 3 level upon TRAIL treatment similar to $\mathrm{Bax}^{+/-}$cells, the major cleavage product was the p24 fragment, and few mature p20 and p17 forms were detected even after $24 \mathrm{~h}$ of TRAIL treatment (Fig. 4A). These results suggest that loss of Bax blocked only the autocatalytic processing of the p24 subunit of caspase- 3 and had no effect on the initial cleavage of caspase- 3 by activated caspase- 8 .

As loss of Bax permitted partial processing of caspase-3 into p24, but not into p20/p17, we investigated whether this partial processing was nonetheless sufficient for its activity in vivo. Caspase- 3 activity was measured by ex-
A

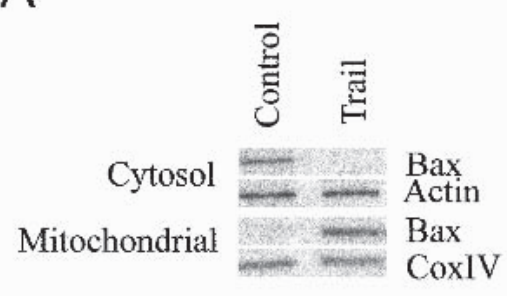

B

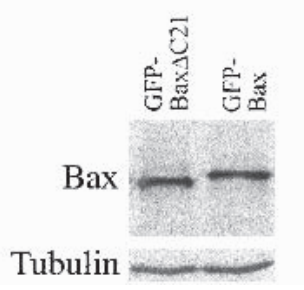

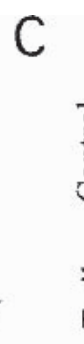
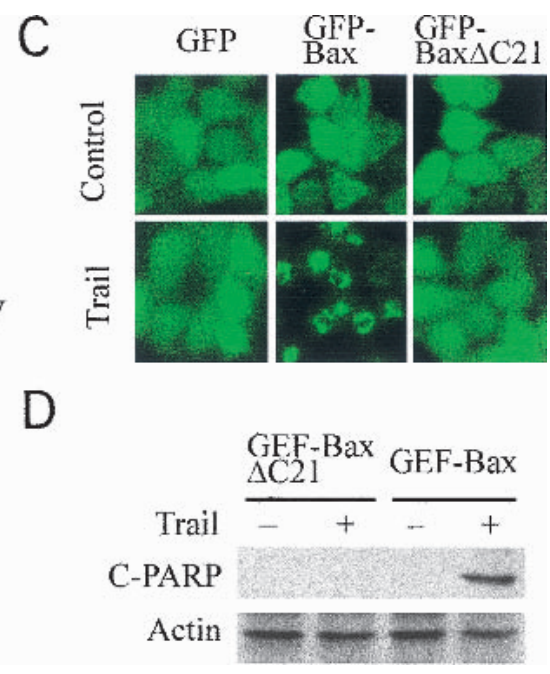

Figure 3. Requirement of Bax translocation in TRAIL-induced apoptosis. (A) Change of Bax distribution after TRAIL treatment. $\mathrm{Bax}^{+/-}$cells were treated by TRAIL, and Bax protein was detected on a Western blot from cytosol and mitochondrial extracts. Cytosol-specific $\beta$-actin and mitochondria-specific cytochrome $c$ oxidase subunit IV (coxIV) were used as loading controls. $(B)$ Expression of GFP-Bax $\Delta \mathrm{C} 21$ protein in a GFPBax $\Delta$ C21 stable cell line. Whole cell extracts were used. $(C)$ Bax distribution changes after TRAIL stimulation. (D) Resistance of GFPBax $\Delta$ C21 cells to TRAIL-induced apoptosis. The apoptosis was measured by detection of C-PARP on Western blots. 


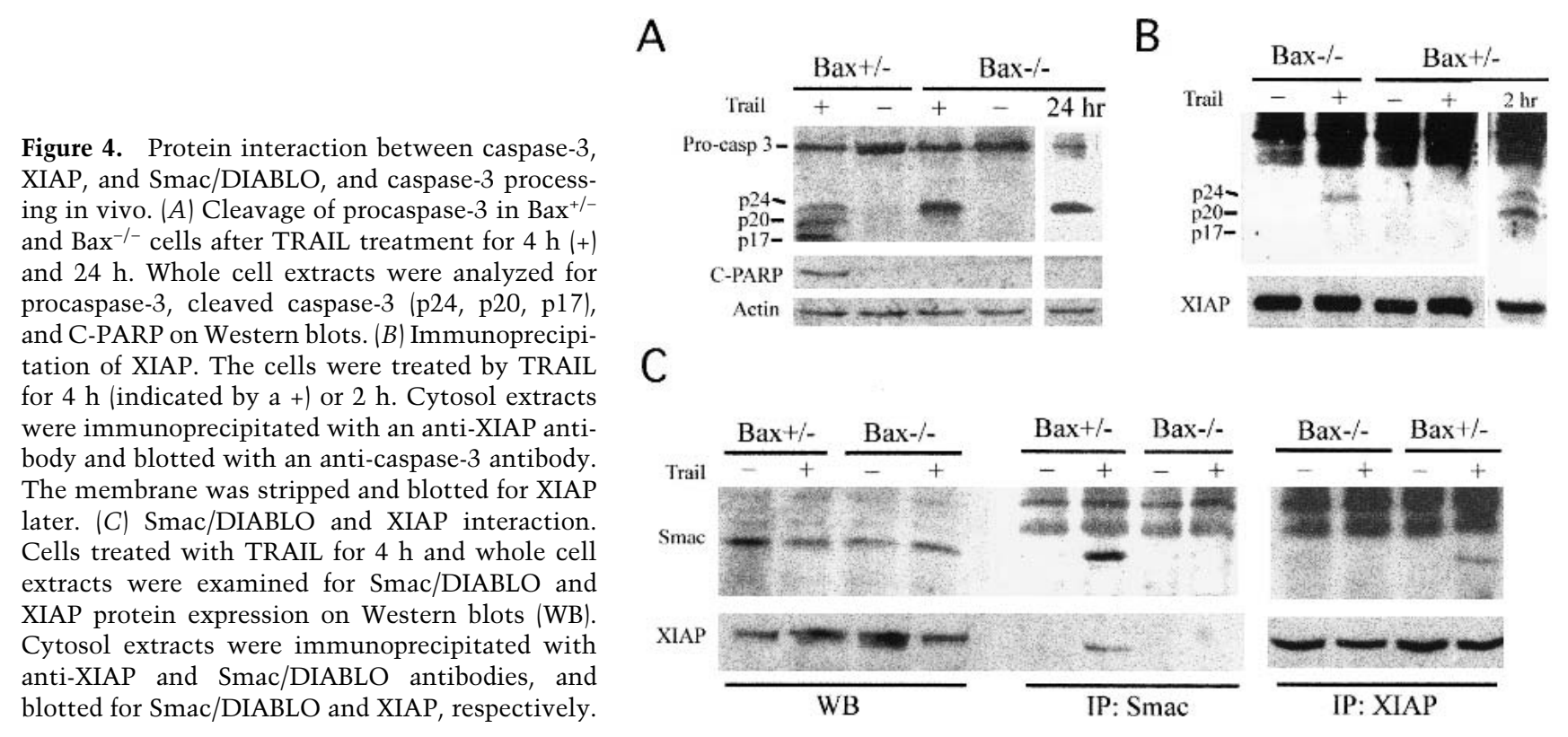

amining the cleavage of its endogenous substrate PARP on Western blots. TRAIL treatment of $\mathrm{Bax}^{+/-}$cells for $4 \mathrm{~h}$ resulted in the appearance of an $85-\mathrm{kD}$ PARP cleavage product (C-PARP), whereas no C-PARP was detected in $\mathrm{Bax}^{-/-}$cells even after $24 \mathrm{~h}$ of TRAIL treatment (Fig. 4A). These results show that the p24 polypeptide is not active in vivo and that a subsequent cleavage event to remove the pro-domain to generate $\mathrm{p} 20 / \mathrm{p} 17$ is required to render caspase- 3 active. Thus, Bax deficiency inhibits PARP cleavage by preventing the removal of the pro-domain of caspase-3.

\section{Regulation of caspase-3 activation by XIAP and Smac/DIABLO in vivo}

To determine whether endogenous XIAP in cancer cells acts on caspase- 3 directly in vivo, the XIAP-caspase-3 interaction was first examined by immunoprecipitations of XIAP using lysates of $\mathrm{Bax}^{+/-}$and $\mathrm{Bax}^{-/-}$cells exposed to TRAIL for $4 \mathrm{~h}$. Although processed forms of caspase- 3 were present in the lysates of both $\mathrm{Bax}^{+/-}$and $\mathrm{Bax}^{-/-}$ cells, immunoprecipitation of XIAP only brought down p24 in the $\mathrm{Bax}^{-/-}$cells (Fig. 4B), suggesting that XIAP and the $\mathrm{p} 24$ form of caspase- 3 form a stable complex in $\mathrm{Bax}^{-/-}$ cells. Association between XIAP and processed caspase-3 was observed at an earlier $(2 \mathrm{~h})$ time point after TRAIL treatment in $\mathrm{Bax}^{+/}$cells (Fig. 4B). The data suggest that the lack of XIAP binding to the processed caspase- 3 in $\mathrm{Bax}^{+/-}$cells is not due to the inability of XIAP to bind to the active caspase- 3 (p20/p17). In agreement with previous reports in vitro (Deveraux et al. 1998), XIAP did not coimmunoprecipitate with the zymogen caspase-3. Attempts to perform immunoprecipitation of caspase- 3 to pull down XIAP proved to be difficult owing to high backgrounds (data not shown). Immunoprecipitation of XIAP brought down processed caspase- 3 only at $2 \mathrm{~h}$ of
TRAIL treatment, whereas processed caspase- 3 was present at both 2 -h and 4 -h time points in the TRAILtreated $\mathrm{Bax}^{+/-}$cells, indicating that the association between XIAP and processed caspase- 3 in $\mathrm{Bax}^{+-}$cells is dynamic. The persistent binding of XIAP to the p24 form of caspase- 3 in $\mathrm{Bax}^{-/-}$cancer cells suggests that interaction between XIAP and p24 inhibited further caspase- 3 cleavage and activation in $\mathrm{Bax}^{-/-}$cancer cells after TRAIL treatment. Because the XIAP-caspase-3 interaction is Bax-dependent, these results also suggest that Bax-dependent factors released from mitochondria or its downstream targets are likely involved in regulating the interaction between processed caspase- 3 and XIAP.

One of the factors released from mitochondria during apoptosis is the Smac/DIABLO protein, which binds and neutralizes the inhibitory activity of IAPs, including $\mathrm{XIAP}$, and allows caspase activation in vitro (Chai et al. 2000). We therefore examined whether Smac/DIABLO is involved in TRAIL-induced procaspase-3 cleavage and enzyme activity in vivo. Association between Smac/ DIABLO and XIAP was analyzed by coimmunoprecipitation of cytosol extracts obtained from $\mathrm{Bax}^{+/-}$and $\mathrm{Bax}^{-/-}$ cells before and after TRAIL treatment. Analysis of whole cell lysates showed that expression of Smac/ DIABLO and XIAP is not affected by TRAIL treatment (Fig. 4C). Consistent with earlier results (Fig. 2C), cytosolic Smac/DIABLO protein was detected only in $\mathrm{Bax}^{+/-}$ cancer cells treated by TRAIL (Fig. 4C). More importantly, it coimmunoprecipitated with XIAP as detected by immunoprecipitation of Smac/DIABLO (Fig. 4C). Conversely, immunoprecipitation of XIAP also coimmunoprecipitated cytosolic Smac/DIABLO in $\mathrm{Bax}^{+/-}$cancer cells treated by TRAIL (Fig. 4C). These results support the argument that Bax-dependent release of Smac/ DIABLO from mitochondria enables Smac/DIABLO to interact with XIAP to disrupt the XIAP-caspase-3 inter- 


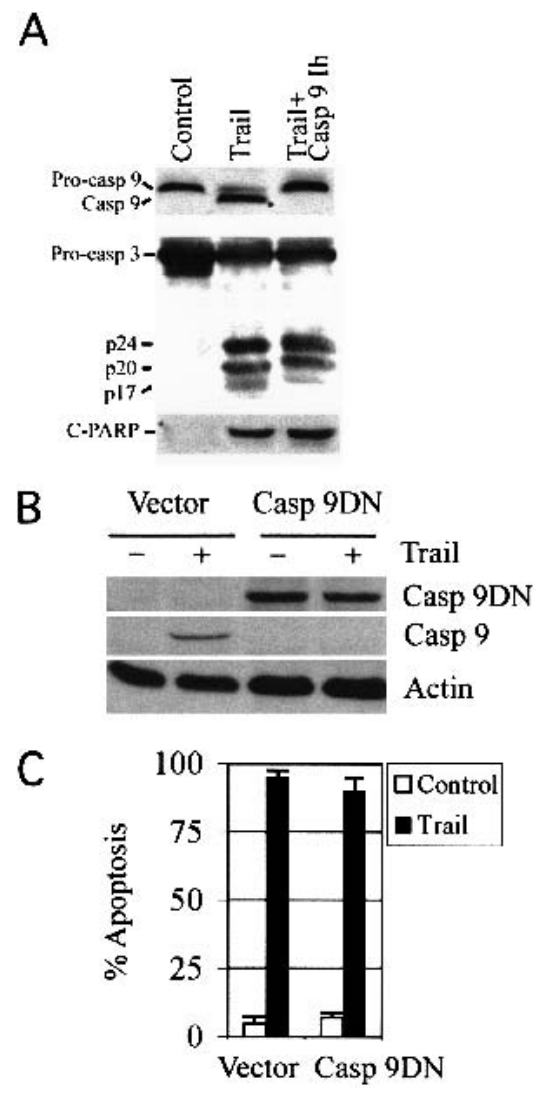

Figure 5. Inhibition of caspase-9 has no effect on caspase-3 processing and TRAIL-mediated apoptosis. $(A) \mathrm{Bax}^{+/-}$cells were treated by TRAIL or a caspase-9 inhibitor (Casp 9Ih) in addition to TRAIL for $4 \mathrm{~h}$. Whole cell extracts were analyzed for caspase9, caspase-3, and C-PARP by Western blots. (B) Expression of casp 9DN blocks procaspase-9 cleavage. $\mathrm{Bax}^{+/-}$cells were transfected with either the dominant-negative casp 9DN DNA or a vector control along with a GFP-expressing plasmid. More than $90 \%$ of the cells were transfected, based on GFP fluorescence. The cells were treated with TRAIL for $4 \mathrm{~h}$ at $48 \mathrm{~h}$ after transfection. The Casp 9DN protein was detected by an anti-Flag antibody, and processed caspase- 9 was detected by an antibody recognizing only the cleaved caspase-9. Actin is used as the loading control. $(C)$ Casp 9DN has no effect on TRAIL-induced apoptosis. Rounded apoptotic GFP-positive cells were counted in triplicate plates, and data were plotted.

action, thus allowing caspase-3 autocleavage and functional activation.

Rescue of TRAIL sensitivity in Bax-deficient cells by cytosolic expression of Smac/DIABLO

We have shown that TRAIL induces the release of cyto $c$ from mitochondria and the subsequent processing of procaspase-9 (Fig. 2). The mature caspase-9, in turn, could activate its primary downstream target, procaspase- 3 . Therefore, we tested whether mature caspase- 9 is required for caspase-3 activation during TRAIL stimulation in vivo using a caspase-9 inhibitor, Z-LEHD-FMK. Addition of Z-LEHD-FMK did not block caspase-3 cleav- age and apoptotic cell death in $\mathrm{Bax}^{+/-}$cancer cells after TRAIL treatment, but strongly inhibited procaspase-9 cleavage and activation (Fig. 5A). To further exclude the involvement of caspase-9 in TRAIL-induced apoptosis, a dominant-negative mutant of caspase-9 (Casp 9DN; Fearnhead et al. 1998) was transfected into $\mathrm{Bax}^{+/-}$cells along with a GFP marker. Expression of Casp 9DN inhibited the generation of cleaved caspase-9 (Fig. 5B), but it had no effect on caspase- 3 processing and cell death after TRAIL treatment (Fig. 5C; data not shown). These results suggest that cyto $c$ release and subsequent caspase- 9 activation are not required for TRAIL-induced apoptosis and that other factors are involved in the process.

Smac/DIABLO is synthesized as a 239-amino-acid precursor molecule. The $\mathrm{N}$-terminal 55 residues contain the mitochondria targeting sequence (MTS) and are removed after import into mitochondria. The mature and functional form of Smac contains 184 amino acids (Du et al. 2000). When a full-length Smac/DIABLO cDNA was transfected into $\mathrm{Bax}^{-/-}$cells, it did not restore TRAIL-induced apoptosis, as indicated by the lack of PARP cleavage (Fig. 6A). Subcellular fraction analysis showed that transfected Smac/DIABLO was localized to mitochondria and remained there after TRAIL treatment (Fig. 6A), consistent with the fact that loss of Bax inhibits Smac/DIABLO release during TRAIL signaling. In $\mathrm{Bax}^{+/-}$cells, transfected Smac/DIABLO is redistributed to the cytosol after TRAIL treatment (Fig. 6A).

It has been shown that modification of the $\mathrm{N}$ terminus of mature Smac/DIALO results in functional deficiency in XIAP binding (Chai et al. 2000; Srinivasula et al. 2001). To generate a functionally active and cytosolic Smac/DIABLO protein, we engineered a Smac/DIABLO expression construct, wherein a cytosolic mature Smac/ DIABLO (deleted MTS) was fused with GFP protein. A caspase- 8 cleavage site (IETD) was introduced between GFP and the mature Smac/DIABLO, which allows the production of authentic mature Smac/DIABLO in the cytosol after caspase- 8 cleavage during TRAIL treatment. A similar construct has been shown to enhance apoptosis in a different system (Srinivasula et al. 2000). This plasmid was transfected into $\mathrm{Bax}^{-/-}$cells, and cell lines stably expressing GFP-Smac were established. As expected, Western blot analysis showed that GFP-Smac fusion protein was generated and cleaved into GFP and mature Smac proteins by activated caspase- 8 after TRAIL treatment (Fig. 6B). More importantly, expression of GFP-Smac completely restored caspase-3 processing, activation, and apoptotic cell death indicated by substrate PARP cleavage in $\mathrm{Bax}^{-/-}$cells after TRAIL treatment (Fig. 6B,C). The protein-protein interaction between Smac/DIABLO and XIAP was also readily observed in GFP-Smac cells following TRAIL treatment (Fig. 6D). The ability of cytosolic Smac/DIABLO to rescue TRAIL-induced apoptosis in $\mathrm{Bax}^{-/-}$cells further supports the argument that XIAP-caspase- 3 interaction in $\mathrm{Bax}^{-1-}$ cells blocks the TRAIL-induced cell death pathway and that release of Smac/DIABLO from mitochon- 
Deng et al.
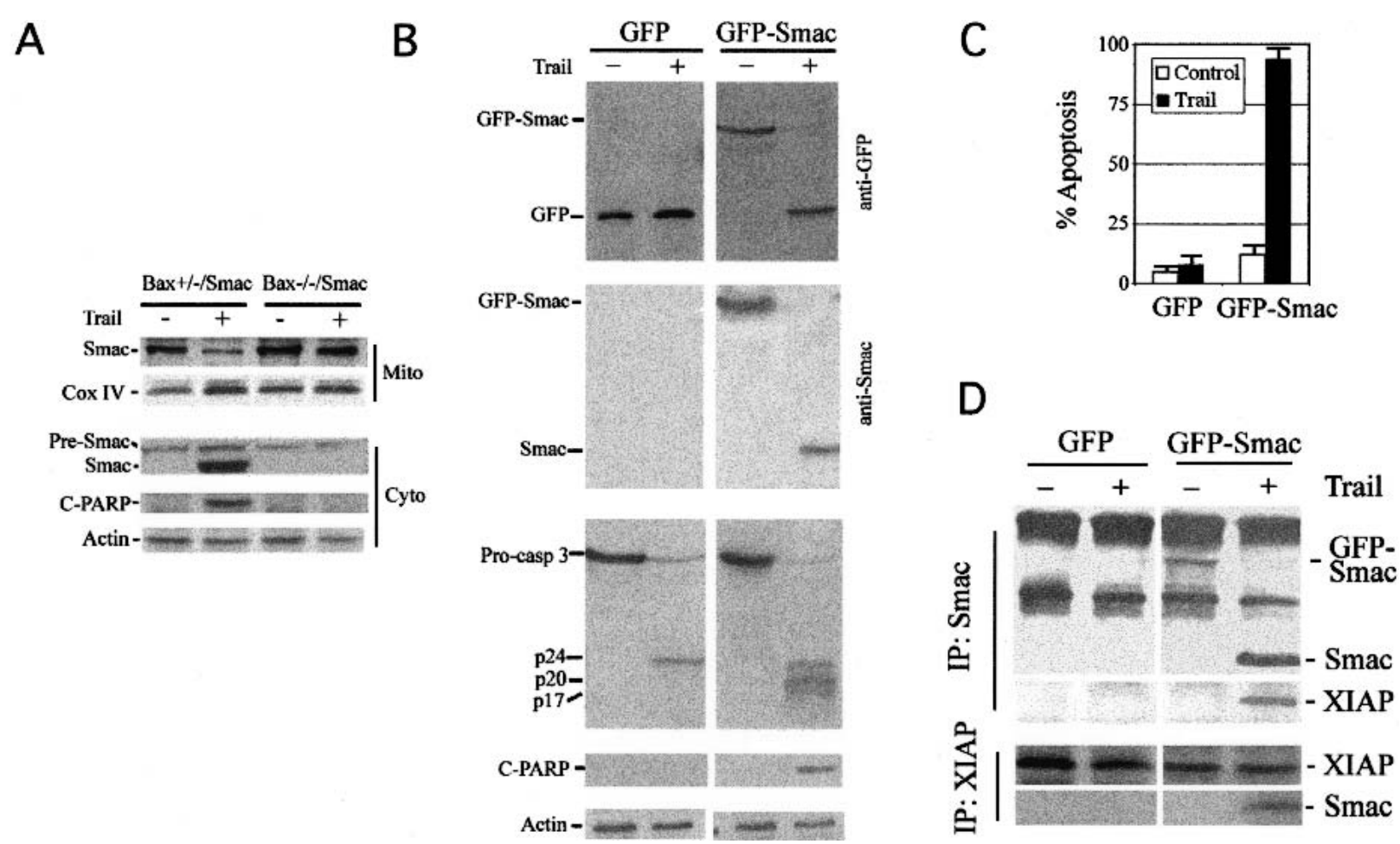

Figure 6. Rescue of TRAIL-induced apoptosis. $(A)$ Expression of a full-length Smac/DIABLO $\mathrm{cDNA}^{-} \mathrm{Bax}^{+/-} / \mathrm{Smac} \mathrm{and} \mathrm{Bax}{ }^{-/-} / \mathrm{Smac}^{-}$ cells express a full-length Smac/DIABLO (Flag-tagged at the C-terminal) derived from $\mathrm{Bax}^{+/-}$and $\mathrm{Bax}^{-/}$cells, respectively. They were treated by TRAIL for $4 \mathrm{~h}$. Mitochondrial and cytosol extracts were prepared. Transfected Smac/DIABLO was detected by an anti-Flag antibody, and apoptosis was measured by detection of C-PARP. (B) Expression of the mature active form of Smac/DIABLO in the cytosol of Bax ${ }^{-/-}$cells. Stable cell lines expressing either GFP or GFP-Smac derived from Bax ${ }^{-/-}$cells were treated by TRAIL for 4 h, and cytosol extracts were analyzed for expression of GFP, GFP-Smac, and Smac/DIABLO using anti-GFP and Smac/DIABLO antibodies, respectively. Processing and activation of caspase-3 were detected by anti-caspase-3 and C-PARP antibodies. Actin was used as the loading control. $(C)$ Quantitation of apoptosis in GFP and GFP-Smac cells. Apoptosis was measured by trypan blue exclusion; data represent three independent experiments. $(D)$ Detection of Smac/DIABLO-XIAP complex in GFP-Smac-expressing cells. Cytosol extracts as described in $B$ were immunoprecipitated with either anti-XIAP or anti-Smac/DIABLO antibodies, and blotted for Smac/ DIABLO or XIAP, respectively.

dria is necessary to remove the XIAP inhibition and allow apoptosis to proceed.

\section{Discussion}

It has been well established that apoptosis mediated through mitochondria and apoptosis mediated through cell death receptors represent distinct pathways by activating different downstream targets. Although both processes result in the activation of common effector caspases, the activation steps are achieved by distinct mechanisms. In the cell death receptor pathway, the effector caspases are activated by caspase- 8 , which is directly activated by death receptors through adapter proteins (for review, see Ashkenazi and Dixit 1998). Mitochondria-mediated apoptosis, however, activates effector caspases by releasing cyto $c$ from mitochondria, with the subsequent activation of caspase-9 (for review, see Green and Reed 1998). Therefore, apoptosis through death receptors does not appear to require the involvement of mitochondria, and Bcl-2/Bcl-xl should have no effect on the apoptosis induced by the death receptors. This ap- pears to be the case in some studies. However, recent reports persistently assert that $\mathrm{Bcl}-2 / \mathrm{Bcl}-\mathrm{xl}$ can inhibit death receptor-triggered apoptosis, and this has led to the controversial idea that there are two different cell types. In type I cells, cell death receptor signaling is not blocked by Bcl-2, whereas in type II cells it is (Scaffidi et al. 1998). It is proposed that in type II cells, the activation of caspase- 8 by death receptors is not sufficient to induce apoptosis but that mitochondria-mediated caspase activation is required to enhance caspase- 8 cleavage and cell death.

We have shown that TRAIL undergoes caspase-8-dependent cell death cascade, consistent with the idea that TRAIL-induced apoptosis is mediated by a common cell death receptor pathway shared by the Fas receptor (CD95) signaling pathway. However, TRAIL-induced cancer cell death appears to have characteristics of both type I and type II cells. First, we have observed that Bcl-xl can block TRAIL-induced cancer cell death and further shown that the mitochondrial pathway is involved for TRAIL through cell death receptor-mediated apoptosis, which is characteristic of type II cells. We have also no- 
ticed that loss of Bax does not affect TRAIL-induced caspase- 8 activation and that caspase- 8 activation is upstream of the mitochondrial signaling pathway, which is characteristic of type I cells. Most importantly, we have shown that mitochondrial cell death events are activated by TRAIL stimulation in a Bax-dependent manner and that Bax expression restores Bax-deficient cells to TRAIL-induced apoptosis. These results indicate that the Bax-mediated mitochondrial pathway is required for TRAIL-induced apoptosis in human cancer cells.

While this manuscript was in preparation, the findings for the essential role of Bax in TRAIL-induced cancer cell death were also observed by another group; however, the mechanism for this requirement was not addressed (Burns and El-Deiry 2001). In addition to TRAIL, we have also found that loss of Bax completely prevents Fas-induced colon cancer cell death and that reexpression of Bax in $\mathrm{Bax}^{-/-}$cells can rescue Fas-induced cell death (Deng et al., unpubl.). These results suggest that Baxinduced mitochondrial events are also required for Fasmediated apoptosis. TNF- $\alpha$ activates not only the FADD-caspase- 8 apoptotic pathway, but also induces the TRAF2-NF-кB anti-apoptotic pathway, which upregulates anti-apoptotic genes, such as IAPs (Wang et al. 1998). Therefore, TNF- $\alpha$-induced cell death requires inhibition of NF- $\mathrm{BB}$ signaling by methods such as inhibition of protein synthesis. We have observed that $\mathrm{Bax}^{-/-}$ cells are sensitive to TNF- $\alpha$ - and protein synthesis inhibitor-induced apoptosis (data not shown), which could be caused by down-regulation of IAPs by inhibiting NF$\kappa \mathrm{B}$ signaling, thus bypassing the requirement for Baxmediated mitochondrial events.

It has been shown that TNF- $\alpha$ and Fas activate mitochondria cascade through caspase-8-mediated cleavage of Bid (Li et al. 1998; Luo et al. 1998). Our results show that TRAIL activates mitochondria through the same pathway, suggesting that these molecules activate mitochondrial-initiated apoptosis via a common mechanism mediated by caspase- 8 and tBid. Recent experiments have shown that Bak and Bax have redundant functions in tBid-induced apoptosis in mouse embryonic fibroblast cells (MEFs; Wei et al. 2000, 2001). We have examined Bak expression by Western blots and found that Bak protein is below detection in colon cancer cells (data not shown). Therefore, it is possible that Bak has similar functions to Bax in tBid-induced cancer cell death in $\mathrm{Bax}^{-/-}$cells. We have further shown that $\mathrm{tBid}$ induces Bax translocation from the cytosol to mitochondria, an additional step required for caspase-8-tBid-induced apoptosis. The data from the Bax translocation mutant Bax $\Delta C 21$ strongly support the idea that Bax translocation is required for Bax to function.

Dissecting the role of Bax in the TRAIL pathway has revealed that cooperation between caspase- 8 activation and mitochondrial signaling is required for complete processing and activation of caspase- 3 in vivo. Loss of Bax results in an incomplete processing of caspase-3, whereas activation of caspase- 8 is not affected during TRAIL signaling. Previous studies in vitro have suggested that caspase- 8 can directly process procaspase- 3 into its active form by two distinct cleavage events. A first step involves cleavage of procaspase-3 at the IETD site by activated caspase- 8 to generate the intermediate p24 (large subunit with pro-domain) and p12 (small subunit). A second autocleavage process is required to remove the pro-domain of p24 to generate the large subunit p20/p17 (Martin et al. 1996). Our in vivo data appear to fit the in vitro caspase-3 activation model. However, unlike the in vitro study where second cleavage proceeds spontaneously (Deveraux et al. 1998), our results indicate that the removal of the pro-domain in vivo depends on the removal of XIAP inhibition. Recent studies have suggested that cooperation between caspase- 8 and caspase- 9 is required for complete processing and activation of caspase- 3 in TNF- $\alpha$-induced apoptosis (Perez and White 2000). However, we have shown that inhibition of caspase- 9 does not block caspase- 3 processing and activation in TRAIL-treated $\mathrm{Bax}^{+/-}$cells, suggesting that caspase- 9 is not required for complete processing and activation of caspase- 3 during TRAIL signaling. We have further observed that activation of caspase-3 by caspase- 8 is blocked by XIAP in cancer cells through interaction between XIAP and partially processed caspase-3 p24. These data suggest that activation of caspase- 8 is necessary but not sufficient for complete processing and activation of caspase- 3 in the TRAIL-mediated cell death pathway.

Smac/DIABLO is identified as a mitochondrial factor involved in apoptosis by removing XIAP inhibition on caspases. The function of Smac/DIABLO is defined mostly by in vitro and overexpression studies (Du et al. 2000; Verhagen et al. 2000; Ekert et al. 2001). We show in this study that Bax-induced mitochondrial release of Smac/DIABLO, not cyto $c$, is required for complete processing and activation of procaspase-3 in vivo at physiological level after TRAIL stimulation. The function of Smac/DIABLO in the cytosol appears to be to dissociate p24-XIAP interaction, as shown by immunoprecipitation experiments. The ability of cytosol active Smac/ DIABLO to restore TRAIL sensitivity in Bax-deficient cells strongly supports the idea that Smac/DIABLO, a mitochondrial factor, is required for the death receptormediated apoptosis pathway. Given that Smac/DIABLO regulates the activation of caspase- 3 in vivo, a common effector caspase in both death receptor- and mitochondria-mediated apoptosis, it is likely that Smac/DIABLO is also a potent regulator in cyto $c$-caspase-9-mediated caspase- 3 activation and apoptosis.

Although the functions of many molecules and genetic pathways involved in mitochondria- and cell death receptor-mediated apoptosis have been well established, our understanding of the interplay between the two pathways remains fragmented. Our data demonstrated for the first time a sequence of signal transduction events that link the two seemingly independent apoptosis pathways together in a single genetic system. Based on the results from both previous reports by others ( Du et al. 2000; Green 2000; Verhagen et al. 2000) and our present studies, we propose a model for the cross-talk between death receptor- and mitochondria-mediated cell 
Deng et al.

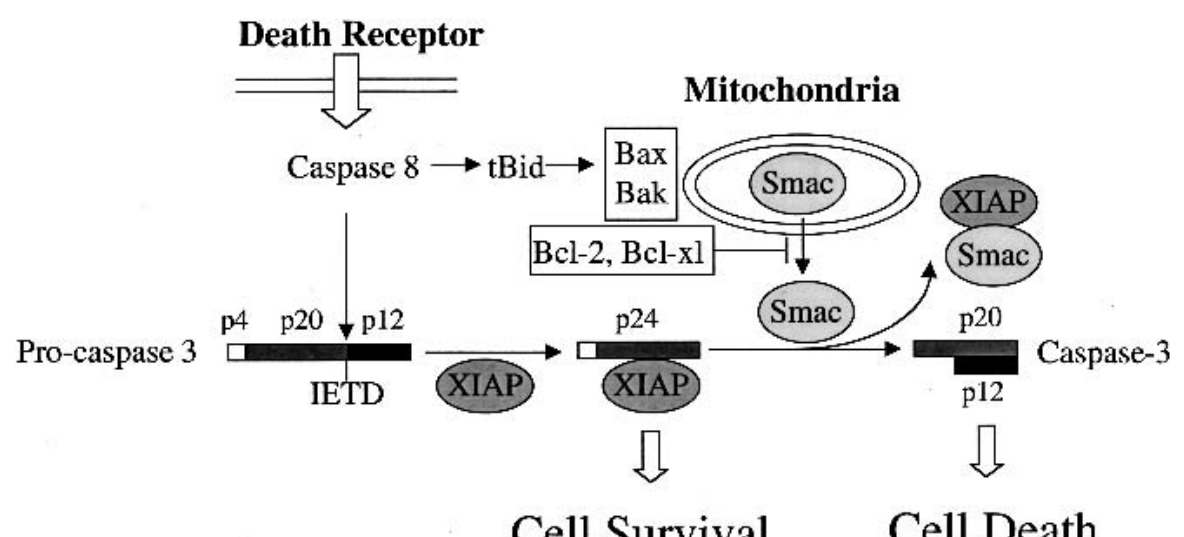

Figure 7. A model for the role of Smac/DIABLO in cell death receptor-mediated apoptosis.

death pathways. Activation of a death receptor leads to the activation of caspase-8, which results in initial cleavage of procaspase-3 to generate p24, a partially processed caspase-3 fragment. The p24 protein directly binds to XIAP and remains inactive; therefore, the apoptosis pathway is blocked and no cell death occurs (Fig. 7). To allow apoptosis to proceed, caspase- 8 is required to cleave Bid to generate tBid, which acts on either Bax or Bak to induce mitochondrial release of Smac/DIABLO protein to the cytosol. Cytosolic Smac/DIABLO then binds to XIAP, eliminates its inhibition of $\mathrm{p} 24$, and allows autocleavage of $\mathrm{p} 24$ to form $\mathrm{p} 20 / \mathrm{p} 17$. Together with p12, an active caspase-3 is formed and apoptosis can proceed (Fig. 7). The levels of XIAP (or other IAPs) in cells will likely determine whether the mitochondrial pathway is essential for death receptor-mediated apoptosis. If cells contain low levels of XIAP, there will be no inhibition on $\mathrm{p} 24$ autocleavage, and mitochondrial release of Smac/DIABLO will not be required for death receptormediated apoptosis. On the other hand, if XIAP expression is high, activation of the mitochondrial pathway will be required to release Smac/DIABLO and remove the inhibition of XIAP. Consistent with this model, MEFs defective in certain factors in the mitochondrial cell death pathway, such as cyto $c$ (Li et al. 2000), Apaf-1 (Cecconi et al. 1998; Yoshida et al. 1998), and caspase-9 (Hakem et al. 1998), are still sensitive to cell death receptor-mediated apoptosis, because the function of Smac/DIABLO remains intact in these cells. However, cells lacking upstream mitochondrial events, such as Bid knockout cells, are more resistant to cell death receptorinduced apoptosis (Yin et al. 1999), likely owing to the fact that release of Smac/DIABLO is blocked in these cells. More recent studies have indicated the presence of the Smac/DIABLO-like molecule HtrA2. HtrA2 is also released from mitochondria to interact with XIAP during apoptosis (Hegde et al. 2001; Martins et al. 2001; Suzuki et al. 2001; Verhagen et al. 2001). Therefore, it is possible that HtrA2 may play a similar role to Smac/DIABLO in the cross-talk between receptor- and mitochondria-mediated apoptosis.

It has been shown that most cancer cells express high levels of XIAP (Tamm et al. 2000). It is therefore likely that TRAIL-induced cancer cell death will require mitochondria involvement. This idea is supported by the fact that DNA damage agents targeting mitochondria greatly enhance TRAIL-mediated apoptosis in cancer cells (Keane et al. 1999). Given that TRAIL is a promising potential anticancer agent, which kills cancer cells while leaves normal cells untouched, understanding the importance of the mitochondrial contribution to TRAILmediated apoptosis is of significance for the development of TRAIL therapy for human cancers. Impairment in mitochondrial activation is frequently associated with cancer development, such as mutations in Bax (Rampino et al. 1997; Ionov et al. 2000), Bak (Kondo et al. 2000), and loss of function of Apaf-1 (Jia et al. 2001; Soengas et al. 2001). Therefore, XIAP and Smac/DIABLO represent potential therapeutic targets to bypass the involvement of the mitochondrial pathway and improve TRAIL cancer therapy.

\section{Materials and methods}

\section{Antibodies and reagents}

The following antibodies were used: anti-Bax (N20), anti-cyto $c$, and anti-caspase-9 polyclonal antibodies (Santa Cruz Biotechnology); anti-caspase- 8 , anti-Bid, and anti-caspase- 3 antibodies (BD PharMingen); anti-Bcl-xl and anti-hILP/XIAP antibodies (BD transduction laboratories); anti-Bak polyclonal antibody (Upstate Biotechnology); anti-cleaved human PARP and anticleaved human caspase-9 (Cell signaling); anti-Smac/DIABLO monoclonal antibody (Calbiochem); anti-Flag monoclonal antibody and anti- $\beta$-actin (Sigma); anti-GFP polyclonal antibody and anti-cytochrome $c$ oxidase subunit IV (Clontech). Z-LEHDFMK, Z-IETD-FMK, and Z-VAD-FMK were obtained from BD PharMingen. The TRAIL apoptosis kit is obtained from Upstate Biotechnology.

\section{Cell lines and transfection}

The human colon cancer HCT116 $\mathrm{Bax}^{+/-}$and $\mathrm{Bax}^{-/-}$cells were kindly provided by Bert Vogelstein at Johns Hopkins University. The cells were maintained as described (Zhang et al. 2000). Transfection was performed with Lipofectamin (Life Technologies) according to the manufacture's instructions. The trans- 
fected cells were harvested $24-48 \mathrm{~h}$ for transient analysis. Stable cell lines, including those expressing Bcl-xl, GFP, GFP-Bax, GFP-Bax $\Delta$ C21, GFP-Smac/DIABLO, were derived by selecting transfected HCT Bax ${ }^{+/-}$or $\mathrm{Bax}^{-/-}$cells in Geneticin $(1 \mathrm{mg} / \mathrm{mL})$ for 4-6 wk.

\section{Plasmids and constructs}

The Bcl-xl expression plasmid was provided by David Spencer at Baylor College of Medicine. Plasmids for expressing Bid, tBid, Smac/DIABLO (generous gifts from Chunying Du, Stowers Institute for Medical Research), and Bax-GFP were described previously (Deng and Wu 2000). A Flag-tagged cDNA for the dominant-negative caspase-9 (casp 9DN, C287S) pUC18 plasmid was provided by Yuri Lazebnik at Cold Spring Harbor Laboratory; it was subcloned into pcDNA3.1 (Invitrogen). $\operatorname{Bax} \Delta \mathrm{C} 21$ was constructed by PCR from $B a x$ cDNA, and GFP-Bax $\Delta C 21$ was generated by cloning the PCR products into the pEGFP-C1 vector (Clontech). Bak was generated by RT-PCR from total RNA isolated from MCF-7 cells and cloning the RT-PCR products into the pEGFP-N1 vector (Clontech). Mature Smac/DIABLO (mSmac) was generated by PCR of Smac/DIABLO cDNA and cloning the PCR products into the pEGFP-C1 vector, between GFP and mSmac, a caspase- 8 cleavage site was introduced by the $5^{\prime}$ primer with ATTGAGACAGAC.

\section{Cell death receptor-induced apoptosis assay}

Cells growing at the log phase were added to the medium to a final concentration of $100 \mathrm{ng} / \mathrm{mL}$ of TRAIL. Cells were harvested after $4 \mathrm{~h}$ of treatment, or at a specific time point as indicated in each experiment. In some experiments, caspase inhibitors were used. The caspase- 8 , caspase- 9 , or general caspase inhibitor was applied at the concentration of $50 \mu \mathrm{M}$ to the medium 30 min prior to treatment. Transient transfected cells were treated $24 \mathrm{~h}$ posttransfection. Cell viability was determined by trypan blue exclusion.

\section{Subcellular fraction and immunofluorescence}

Subcellular fraction was performed as described previously (Deng and Wu 2000). The purity of the extracts was tested by Western blotting against cytosol-specific $\beta$-actin and mitochondria-specific cytochrome $c$ oxidase subunit IV (coxIV). The protein concentrations in cytosol and mitochondria were determined, and aliquots were stored at $-80^{\circ} \mathrm{C}$. Cells were seeded on glass chamber slides, and the immunostaining procedure was performed as previously described (Deng and Wu 2000) by using primary rabbit anti-Smac polyclonal antibody (1:200), or rabbit anti-cytochrome $c$ antibody (1:500), and secondary rhodamineconjugated antibody against rabbit (Sigma, 1:1000). Hochest 3342 (Molecular Probes) was used to visualized the nuclei. The slides were mounted and viewed by fluorescence microscope (Nikon).

\section{Immunoprecipitation and Western analysis}

Cells were either left untreated or treated with TRAIL for $4 \mathrm{~h}$ or at the specific indicated time point. All cells were harvested and resuspended in Chaps cell extract buffer (cell signaling) by sonication on ice. Lysates were clarified by centrifugation at $14,000 \mathrm{~g}$ at $4^{\circ} \mathrm{C}$ for $15 \mathrm{~min}$. Cytosol extracts were precleared, then incubated with antibody against XIAP or Smac and protein A Sepharose (GIBCO BRL) for pulling down immune complexes. The Sepharose was washed three times with lysis buffer and two times with PBS. Western blotting of cytosol, mitochondria ex- tracts, total lysates, and immunoprecipitates was performed as previously described (Deng and Wu 2000).

\section{Acknowledgments}

We thank H. Zheng and members of her laboratory at Baylor College of Medicine for helpful discussions, and N. Aithmitti and L. Yang for assistance of this work. We also thank B. Vogelstein at Johns Hopkins Medical School for providing $\mathrm{Bax}^{+/-}$ and $\mathrm{Bax}^{-/-}$cells, D. Spencer at Baylor College of Medicine for $B c l-x l$ cDNA, and Yuri Lazebnik and Junying Yuan for Casp $9 D N$ cDNA. This work was supported by grants from NCI (to X.W.).

The publication costs of this article were defrayed in part by payment of page charges. This article must therefore be hereby marked "advertisement" in accordance with 18 USC section 1734 solely to indicate this fact.

\section{References}

Ashkenazi, A. and Dixit, V.M. 1998. Death receptors: Signaling and modulation. Science 281: 1305-1308.

Ashkenazi, A., Pai, R.C., Fong, S., Leung, S., Lawrence, D.A., Marsters, S.A., Blackie, C., Chang, L., McMurtrey, A.E., Hebert, A., et al. 1999. Safety and antitumor activity of recombinant soluble Apo2 ligand. J. Clin. Invest. 104: 155-162.

Bodmer, J.L., Holler, N., Reynard, S., Vinciguerra, P., Schneider, P., Juo, P., Blenis, J., and Tschopp, J. 2000. TRAIL receptor-2 signals apoptosis through FADD and caspase-8. Nat. Cell Biol. 2: 241-243.

Burns, T.F. and El-Deiry, W.S. 2001. Identification of inhibitors of TRAIL-induced death (ITIDs) in the TRAIL sensitive colon carcinoma cell line, SW480, using a genetic approach. J. Biol. Chem. 2: 37879-37886.

Cecconi, F., Alvarez-Bolado, G., Meyer, B.I., Roth, K.A., and Gruss, P. 1998. Apaf1 (CED-4 homolog) regulates programmed cell death in mammalian development. Cell 94: $727-737$.

Chai, J., Du, C., Wu, J.W., Kyin, S., Wang, X., and Shi, Y. 2000. Structural and biochemical basis of apoptotic activation by Smac/DIABLO. Nature 406: 855-862.

Deng, Y. and $\mathrm{Wu}, \mathrm{X}$. 2000. Peg3/Pw1 promotes p53-mediated apoptosis by inducing Bax translocation from cytosol to mitochondria. Proc. Natl. Acad. Sci. 97: 12050-12055.

Deveraux, Q.L., Takahashi, R., Salvesen, G.S., and Reed, J.C. 1997. X-linked IAP is a direct inhibitor of cell-death proteases. Nature 388: 300-304.

Deveraux, Q.L., Roy, N., Stennicke, H.R., Van Arsdale, T., Zhou, Q., Srinivasula, S.M., Alnemri, E.S., Salvesen, G.S., and Reed, J.C. 1998. IAPs block apoptotic events induced by caspase- 8 and cytochrome c by direct inhibition of distinct caspases. $E M B O$ J. 17: 2215-2223.

Du, C., Fang, M., Li, Y., Li, L., and Wang, X. 2000. Smac, a mitochondrial protein that promotes cytochrome c-dependent caspase activation by eliminating IAP inhibition. Cell 102: 33-42.

Ekert, P.G., Silke, J., Hawkins, C.J., Verhagen, A.M., and Vaux, D.L. 2001. DIABLO promotes apoptosis by removing MIHA/ XIAP from processed caspase 9. J. Cell Biol. 152: 483-490.

Fearnhead, H.O., Rodriguez, J., Govek, E.E., Guo, W., Kobayashi, R., Hannon, G., and Lazebnik, Y.A. 1998. Oncogenedependent apoptosis is mediated by caspase-9. Proc. Natl. Acad. Sci. 95: 13664-13669.

French, L.E. and Tschopp, J. 1999. The TRAIL to selective tu- 
mor death. Nat. Med. 5: 146-147.

Goyal, L. 2001. Cell death inhibition: Keeping caspases in check. Cell 104: 805-808.

Green, D.R. 1998. Apoptotic pathways: The roads to ruin. Cell 94: 695-698.

- 2000. Apoptotic pathways: Paper wraps stone blunts scissors. Cell 102: 1-4.

Green, D.R. and Reed, J.C. 1998. Mitochondria and apoptosis. Science 281: 1309-1312.

Hakem, R., Hakem, A., Duncan, G.S., Henderson, J.T., Woo, M., Soengas, M.S., Elia, A., de la Pompa, J.L., Kagi, D., Khoo, W., et al. 1998. Differential requirement for caspase 9 in apoptotic pathways in vivo. Cell 94: 339-352.

Hegde, R., Srinivasula, S.M., Zhang, Z., Wassell, R., Mukattash, R., Cilenti, L., DuBois, G., Lazebnik, Y., Zervos, A.S., Fernandes-Alnemri, T., et al. 2001. Identification of Omi/HtrA2 as a mitochondrial apoptotic serine protease that disrupts IAP-caspase interaction. J. Biol. Chem. Oct 17: epub ahead of print.

Holcik, M., Yeh, C., Korneluk, R.G., and Chow, T. 2000. Translational upregulation of $\mathrm{X}$-linked inhibitor of apoptosis (XIAP) increases resistance to radiation induced cell death. Oncogene 19: 4174-4177.

Hsu, Y.T., Wolter, K.G., and Youle, R.J. 1997. Cytosol-to-membrane redistribution of $\mathrm{Bax}$ and $\mathrm{Bcl}-\mathrm{X}(\mathrm{L})$ during apoptosis Proc. Nat1. Acad. Sci. 94: 3668-3672.

Ionov, Y., Yamamoto, H., Krajewski, S., Reed, J.C., and Perucho, M. 2000. Mutational inactivation of the proapoptotic gene BAX confers selective advantage during tumor clonal evolution. Proc. Natl. Acad. Sci. 97: 10872-10877.

Jia, L., Srinivasula, S.M., Liu, F.T., Newland, A.C., FernandesAlnemri, T., Alnemri, E.S., and Kelsey, S.M. 2001. Apaf-1 protein deficiency confers resistance to cytochrome c-dependent apoptosis in human leukemic cells. Blood 98: 414-421.

Jurgensmeier, J.M., Xie, Z., Deveraux, Q., Ellerby, L., Bredesen, D., and Reed, J.C. 1998. Bax directly induces release of cytochrome c from isolated mitochondria. Proc. Natl. Acad. Sci. 95: 4997-5002.

Keane, M.M., Ettenberg, S.A., Nau, M.M., Russell, E.K., and Lipkowitz, S. 1999. Chemotherapy augments TRAIL-induced apoptosis in breast cell lines. Cancer Res. 59: 734741.

Kischkel, F.C., Lawrence, D.A., Chuntharapai, A., Schow, P., Kim, K.J., and Ashkenazi, A. 2000. Apo2L/TRAIL-dependent recruitment of endogenous FADD and caspase- 8 to death receptors 4 and 5. Immunity 12: 611-620.

Kondo, S., Shinomura, Y., Miyazaki, Y., Kiyohara, T., Tsutsui, S., Kitamura, S., Nagasawa, Y., Nakahara, M., Kanayama, S., and Matsuzawa, Y. 2000. Mutations of the bak gene in human gastric and colorectal cancers. Cancer Res. 60: 43284330.

Kuida, K., Haydar, T.F., Kuan, C.Y., Gu, Y., Taya, C., Karasuyama, H., Su, M.S., Rakic, P., and Flavell, R.A. 1998. Reduced apoptosis and cytochrome c-mediated caspase activation in mice lacking caspase 9. Cell 94: 325-337.

Li, H., Zhu, H., Xu, C.J., and Yuan, J. 1998. Cleavage of BID by caspase 8 mediates the mitochondrial damage in the Fas pathway of apoptosis. Cell 94: 491-501.

Li, K., Li, Y., Shelton, J.M., Richardson, J.A., Spencer, E., Chen, Z.J., Wang, X., and Williams, R.S. 2000. Cytochrome c deficiency causes embryonic lethality and attenuates stress-induced apoptosis. Cell 101: 389-399.

Li, L.Y., Luo, X., and Wang, X. 2001. Endonuclease G is an apoptotic DNase when released from mitochondria. Nature 412: 95-99.

Li, P., Nijhawan, D., Budihardjo, I., Srinivasula, S.M., Ahmad,
M., Alnemri, E.S., and Wang, X. 1997. Cytochrome c and dATP-dependent formation of Apaf-1/caspase-9 complex initiates an apoptotic protease cascade. Cell 91: 479-489.

Liu, X., Kim, C.N., Yang, J., Jemmerson, R., and Wang, X. 1996. Induction of apoptotic program in cell-free extracts: Requirement for dATP and cytochrome c. Cell 86: 147-157.

Luo, X., Budihardjo, I., Zou, H., Slaughter, C., and Wang, X. 1998. Bid, a Bcl2 interacting protein, mediates cytochrome $\mathrm{c}$ release from mitochondria in response to activation of cell surface death receptors. Cell 94: 481-490.

Martin, S.J., Amarante-Mendes, G.P., Shi, L., Chuang, T.H., Casiano, C.A., O'Brien, G.A., Fitzgerald, P., Tan, E.M., Bokoch, G.M., Greenberg, A.H., et al. 1996. The cytotoxic cell protease granzyme B initiates apoptosis in a cell- free system by proteolytic processing and activation of the ICE/CED-3 family protease, CPP32, via a novel two-step mechanism. EMBO J. 15: 2407-2416.

Martins, L.M., Iaccarino, I., Tenev, T., Gschmeissner, S., Totty, N.F., Lemoine, N.R., Savopoulos, J., Gray, C.W., Creasy, C.L., Dingwall, C., et al. 2001. The serine protease Omi/ HtrA2 regulates apoptosis by binding XIAP through a Reaper-like motif. J. Biol. Chem. Oct 15: epub ahead of print.

Miyazaki, T. and Reed, J.C. 2001. A GTP-binding adapter protein couples TRAIL receptors to apoptosis-inducing proteins. Nat. Immunol. 2: 493-500.

Nagata, S. 1997. Apoptosis by death factor. Cell 88: 355-365.

Pan, G., Ni, J., Wei, Y.F., Yu, G., Gentz, R., and Dixit, V.M. 1997a. An antagonist decoy receptor and a death domaincontaining receptor for TRAIL. Science 277: 815-818.

Pan, G., O'Rourke, K., Chinnaiyan, A.M., Gentz, R., Ebner, R., Ni, J., and Dixit, V.M. 1997b. The receptor for the cytotoxic ligand TRAIL. Science 276: 111-113.

Perez, D. and White, E. 2000. TNF- $\alpha$ signals apoptosis through a bid-dependent conformational change in Bax that is inhibited by E1B 19K. Mol. Cell 6: 53-63.

Pitti, R.M., Marsters, S.A., Ruppert, S., Donahue, C.J., Moore, A., and Ashkenazi, A. 1996. Induction of apoptosis by Apo-2 ligand, a new member of the tumor necrosis factor cytokine family. J. Biol. Chem. 271: 12687-12690.

Rampino, N., Yamamoto, H., Ionov, Y., Li, Y., Sawai, H., Reed, J.C., and Perucho, M. 1997. Somatic frameshift mutations in the BAX gene in colon cancers of the microsatellite mutator phenotype. Science 275: 967-969.

Sasaki, H., Sheng, Y., Kotsuji, F., and Tsang, B.K. 2000. Downregulation of $\mathrm{X}$-linked inhibitor of apoptosis protein induces apoptosis in chemoresistant human ovarian cancer cells. Cancer Res. 60: 5659-5666.

Scaffidi, C., Fulda, S., Srinivasan, A., Friesen, C., Li, F., Tomaselli, K.J., Debatin, K.M., Krammer, P.H., and Peter, M.E. 1998. Two CD95 (APO-1/Fas) signaling pathways. EMBO J. 17: $1675-1687$.

Sheridan, J.P., Marsters, S.A., Pitti, R.M., Gurney, A., Skubatch, M., Baldwin, D., Ramakrishnan, L., Gray, C.L., Baker, K., Wood, W.I., et al. 1997. Control of TRAIL-induced apoptosis by a family of signaling and decoy receptors. Science 277: 818-821.

Shimizu, S., Narita, M., and Tsujimoto, Y. 1999. Bcl-2 family proteins regulate the release of apoptogenic cytochrome $\mathrm{c}$ by the mitochondrial channel VDAC. Nature 399: 483-487.

Soengas, M.S., Capodieci, P., Polsky, D., Mora, J., Esteller, M., Opitz-Araya, X., McCombie, R., Herman, J.G., Gerald, W.L., Lazebnik, Y.A., et al. 2001. Inactivation of the apoptosis effector Apaf-1 in malignant melanoma. Nature 409: 207-211.

Sprick, M.R., Weigand, M.A., Rieser, E., Rauch, C.T., Juo, P., Blenis, J., Krammer, P.H., and Walczak, H. 2000. FADD/ MORT1 and caspase- 8 are recruited to TRAIL receptors 1 
and 2 and are essential for apoptosis mediated by TRAIL receptor 2. Immunity 12: 599-609.

Srinivasula, S.M., Datta, P., Fan, X.J., Fernandes-Alnemri, T., Huang, Z., and Alnemri, E.S. 2000. Molecular determinants of the caspase-promoting activity of Smac/DIABLO and its role in the death receptor pathway. J. Biol. Chem. 275: 36152-36157.

Srinivasula, S.M., Hegde, R., Saleh, A., Datta, P., Shiozaki, E., Chai, J., Lee, R.A., Robbins, P.D., Fernandes-Alnemri, T., Shi, Y., et al. 2001. A conserved XIAP-interaction motif in caspase-9 and Smac/DIABLO regulates caspase activity and apoptosis. Nature 410: 112-116.

Stennicke, H.R., Jurgensmeier, J.M., Shin, H., Deveraux, Q., Wolf, B.B., Yang, X., Zhou, Q., Ellerby, H.M., Ellerby, L.M., Bredesen, D., et al. 1998. Pro-caspase-3 is a major physiologic target of caspase-8. J. Biol. Chem. 273: 27084-27090.

Susin, S.A., Lorenzo, H.K., Zamzami, N., Marzo, I., Snow, B.E., Brothers, G.M., Mangion, J., Jacotot, E., Costantini, P., Loeffler, M., et al. 1999. Molecular characterization of mitochondrial apoptosis-inducing factor. Nature 397: 441-446.

Suzuki, Y., Imai, Y., Nakayama, H., Takahashi, K., Takio, K., and Takahashi, R. 2001. A serine protease, HtrA2, is released from the mitochondria and interacts with XIAP, inducing cell death. Mol. Cell 8: 613-621.

Tamm, I., Kornblau, S.M., Segall, H., Krajewski, S., Welsh, K., Kitada, S., Scudiero, D.A., Tudor, G., Qui, Y.H., Monks, A., et al. 2000. Expression and prognostic significance of IAPfamily genes in human cancers and myeloid leukemias. Clin. Cancer Res. 6: 1796-1803.

Verhagen, A.M., Ekert, P.G., Pakusch, M., Silke, J., Connolly, L.M., Reid, G.E., Moritz, R.L., Simpson, R.J., and Vaux, D.L. 2000. Identification of DIABLO, a mammalian protein that promotes apoptosis by binding to and antagonizing IAP proteins. Cell 102: 43-53.

Verhagen, A.M., Silke, J., Ekert, P.G., Pakusch, M., Kaufmann, H., Connolly, L.M., Day, C.L., Tikoo, A., Burke, R., Wrobel, C., et al. 2001. HtrA2 promotes cell death through its serine protease activity and its ability to antagonise inhibitor of apoptosis proteins. I. Biol. Chem. Oct 16: epub ahead of print.

Walczak, H., Miller, R.E., Ariail, K., Gliniak, B., Griffith, T.S., Kubin, M., Chin, W., Jones, J., Woodward, A., Le, T., et al. 1999. Tumoricidal activity of tumor necrosis factor-related apoptosis-inducing ligand in vivo. Nat. Med. 5: 157-163.

Wang, C.Y., Mayo, M.W., Korneluk, R.G., Goeddel, D.V., and Baldwin, A.S., Jr. 1998. NF-кB antiapoptosis: Induction of TRAF1 and TRAF2 and c-IAP1 and c- IAP2 to suppress caspase-8 activation. Science 281: 1680-1683.

Wei, M.C., Lindsten, T., Mootha, V.K., Weiler, S., Gross, A., Ashiya, M., Thompson, C.B., and Korsmeyer, S.J. 2000. tBID, a membrane-targeted death ligand, oligomerizes BAK to release cytochrome c. Genes \& Dev. 14: 2060-2071.

Wei, M.C., Zong, W.X., Cheng, E.H., Lindsten, T., Panoutsakopoulou, V., Ross, A.J., Roth, K.A., MacGregor, G.R., Thompson, C.B., and Korsmeyer, S.J. 2001. Proapoptotic BAX and BAK: A requisite gateway to mitochondrial dysfunction and death. Science 292: 727-730.

Wiley, S.R., Schooley, K., Smolak, P.J., Din, W.S., Huang, C.P., Nicholl, J.K., Sutherland, G.R., Smith, T.D., Rauch, C., Smith, C.A., et al. 1995. Identification and characterization of a new member of the TNF family that induces apoptosis. Immunity 3: 673-682.

Yin, X.M., Wang, K., Gross, A., Zhao, Y., Zinkel, S., Klocke, B., Roth, K.A., and Korsmeyer, S.J. 1999. Bid-deficient mice are resistant to Fas-induced hepatocellular apoptosis. Nature 400: 886-891.
Yoshida, H., Kong, Y.Y., Yoshida, R., Elia, A.J., Hakem, A., Hakem, R., Penninger, J.M., and Mak, T.W. 1998. Apaf1 is required for mitochondrial pathways of apoptosis and brain development. Cell 94: 739-750.

Zhang, L., Yu, J., Park, B.H., Kinzler, K.W., and Vogelstein, B. 2000. Role of BAX in the apoptotic response to anticancer agents. Science 290: 989-992. 


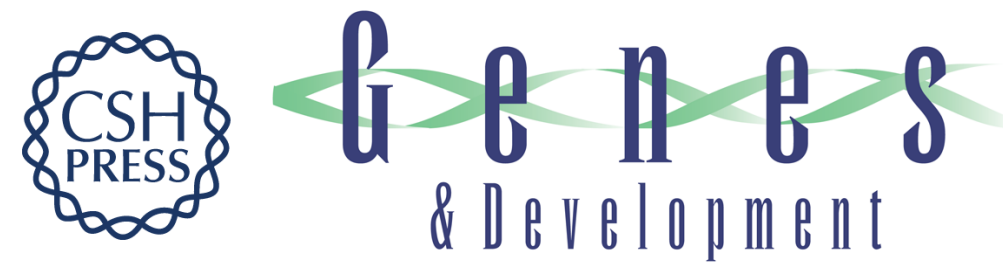

\section{TRAIL-induced apoptosis requires Bax-dependent mitochondrial release of Smac/DIABLO}

Yibin Deng, Yahong Lin and Xiangwei Wu

Genes Dev. 2002, 16:

Access the most recent version at doi:10.1101/gad.949602

References This article cites 65 articles, 26 of which can be accessed free at: http://genesdev.cshlp.org/content/16/1/33.full.html\#ref-list-1

License

Email Alerting Receive free email alerts when new articles cite this article - sign up in the box at the top Service right corner of the article or click here.

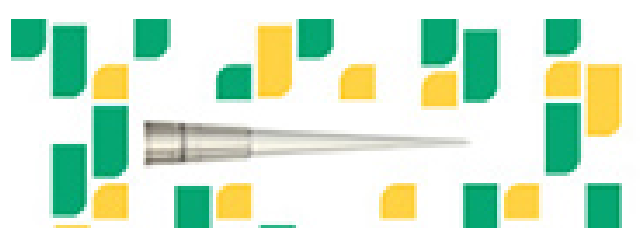

Focused on your science. 